\title{
Integrated Technology And Mutual Participation For Changing Communities Socially, Economically And Religiously
}

\author{
Edi Sunjayanto Maskuri ${ }^{1}$, Yusro Al Hakim ${ }^{2}$ Ashari $^{3}$, Supriyono ${ }^{4}$ \\ \{ esunjayanto@umpwr.ac.id, yusro_alhakim@umpwr.ac.id, azha_ump60@yahoo.com, \\ sjtump@yahoo.com\}
}

Universitas Muhammadiyah Purworejo, Purworejo, Indonesia ${ }^{1}$

\begin{abstract}
Indonesia needs smart technology which is possible to change the life better socially, economically and religiously. It study is multidisciplinary research; social and technic. We use descriptive and qualitative method. We made observation to find out the problem then apply the need using necessary technology. Since we have done the first step, we built the solar system to change into electricity in a field Bandungan, Kajen, Pekalongan. This is historical area where the youth fought again VOC and the treacherous PKI. There is no activity in night, but in day is very busy. Some communities use it for sport activity and the other is for togetherness. The purposes of the study are knowing the necessary technology for make a bridge between three communities in public area, how to apply the cheap and easy solar cell system for public area, and how the effectiveness of the system for changing better life.
\end{abstract}

Keywords: technology, social participation and social changing.

\section{Introduction}

The development of society is growing up. Something may be hidden, forgotten or even lost. It will be changed by others, like value of a culture. Modernization and life style change society both physically or psychologically both better or worse. modernization has given the poor an entitlement to progress but it has been used as an instrument for sometimes brutal forms of intervention. [1] thus has negative impact in social. Yet, new culture will transform gradually because of society changing, new discovery, intercultural contact. [2] Modernization is affecting the lifestyle of human beings with the passage of time. It transforms the norms, values, traditions and other activities of their lives. [3] This side is positive impact. In Economic theory, there appears two impacts: the degree of individualism as the fraction of time that members of society work by themselves and enjoy only the output of their own activity and the degree of collectivism as the complementary fraction of time that members of society work together and enjoy the output of the group activity. [4] There is a growing acknowledgement of the importance of the social interactive dimension of learning.

In this article, the researchers try to underline that it is important to build togetherness in social life when they lose social interaction. The cognitive theories are supposed to be suitable one for this case. The previous study about how to solve the problem in a group, learning together and playing a game/ technology [5]. And the word 'togetherness' is the answer. The dimension of 'togetherness' is here proposed as a descriptor of the aspect of involvement of the 
individual in a group's activity. togetherness is classified into at least three broader categories: (1) togetherness related to emotions, empathy and loyalty, (2) togetherness related to special attention to each other, and (3) togetherness related to cooperation. [6] Many different strategies can be used for this purpose, type of work or activities. It influences on attitudes, behaviors, and cognitions that occur within the team or social group.

In this regard, the social changing will be existed if people/ group of people are considered in social participation, working together to solve such a problem. The aims of the study are to create the social participation by using technology, describe how does the technology work and explain descriptively the positive impact of technology in social, economy and religion.

\section{Method}

The approach of this study is qualitative. It is done to analyze the changing human perspective by a certain strategy with interactive and flexible participants. According to [7] that qualitative research is research process to understand the social phenomena problem by analyzing the process. The data collecting is by interview-based data, observation-based participation and study case. [8] said that the data analysis is process of finding and arranging the data systematically. The analysis data of social phenomena is appropriated with this research because the selected data is the reduction from the participants and it will help the researcher find the solution. We use visual/graphic/ilustration data because it can be fairly raw data, such as photographs or video recordings. It is to recode other types of data, as when logic models describe a theory of change and a program of action or when bar graphs describe a statistical distribution.[9]

\section{Results and Discussion}

\subsection{Modernization, Psychological Egoism, Self Interest and Technology}

According to Smelser's analysis, modern societies have the particular feature of social structural differentiation, have increased the functional capacity of modern organizations. [10] As we know this concept of modernization connected with the utilization of natural resources is based on a technology, which respects the cultural features of the population of a given country. [11] The homogenous society split them into two sides. Psychological egoism is the claim that all our motivational states are ultimately egoistic; psychological altruism is the claim that some of our motivational states are ultimately altruistic.[12] they have the other's benefit rather than the agent's own for its ultimate object (other-directed desires) [13] and self interest is different one, current literature largely describes professional counselors' self-interest in terms of personal wellness, self-advocacy, positive beliefs, self-care and the development of self-regulatory systems.[14] Therefore they get self-sacrifice for the benefit of others.

There is no one stops in a certain point in his/her life. He/she may move gradually so that he/she does not aware of that.[15]. There is theory of modern states about changing that the success of any innovation is dependent on the communication channels used to transmit information about that innovation, receptivity of the social system receiving the communication, and recognition by the social system that the innovation will provide a relative advantage over the status quo. [16]. In two theories, we can conclude that people will open in changing so we need support from all sides to hange people and develop the society, especially about mutual participation or helping each other. It will succeed if there is any communication, innovation, social awareness. 


\subsection{The Description of Research Object}

Bandungan, one of villages in Pekalongan district has a similar character like urban. The center of district Pekalongan. New comers has been living there for a job. They are modern and open minded but they are minor. Some are from higher land or the hill of Slamet Mountain. They are traditional and conservative. The last is the native, they are landlord and own business. According to the history of Pekalongan district, they have made this place heterogeneous. Nevertheless, the researchers made a split based on the interest. They are devided into big three communities; the sporty, religious and commercial community. Recently, in five years, the big three communities developed the public place as identity of their communities. They are: an Islamic center, football club school and business market; shop, bank and hotel. Three communities run the village development better. The three communities then became the sample of subject.

The modernism has two impacts; good and bad. The good one is the existence of media and technology has been growing up like internet access. The bad impact is the less of togetherness and individualistic. It influenced on social, economic and religious activity. Some might say discredited, position: psychological egoism and some say they are motivated in selfinterest.[17]. Psychological egoism is implies an important truth that is often obscured in moral discourse, namely, that pure altruism is an impossible ideal. [12] and self-interest is realistic. It is rational, enlightened, involving disregard for others. So it has positive conotation; personal wellness, self-advocacy, positive beliefs, self-care and the development of self-regulatory systems. [18].

After observation, the researchers determined to solve the problem by stimulating the group of people in one activity. people who live apart. The word 'togetherness' is often considered important for humans, although the reasons or causes behind the creation of this condition may be different and not always clear. More expectations behind it and it should be driven to create togetherness. The tendency towards togetherness sometimes seems to be a social emotional value, with a strong ethical dimension in it, as in saying that humans share the world and thus, for instance, should live harmoniously together and use the world together It was proven by the number of crime rate. [19]

2.3 The Technology Building

There is released land which usually used for converging of ceremony. It is not for planting or agriculture. Some people says that this land is mass burial when Indonesia Comunist Party (PKI) was exist in 1961-965 and they killed and buried people there. Thus, it has been remaining spooky. This area was closed for any activity at night. After undertaken by district authority, this area is called Lapangan Nasional (National Field).

According to interview-based data, observation-based participation and study case, the researchers find three problems; there is no any valiant action from people to change previous perspective from irrational to practical, less participation to cooperative and partisipative, egoism to altruism. The object of three communities to solve the problem and there is no awareness to emphasize the innovation for social needs.

Based on the purpose of study is to find out the solution of; the valiant movement to change previous perspective from irrational to practical, the mutual participation from three communities to change people and how to make people aware of the innovation for social needs. After observation, we analyze all data and team of researcher made a treatment. By designing technology to unhide the value of social participation. There are theories of education which we used for this case that technology has had a major impact on the way communication takes place in school [20]. The value of good communication practices in schools is important to their overall operation and to how efficiently and effectively teachers and students perform [8]. He said in his research that the rise of and application of technology, there is a great opportunity for knowledge building, community interaction, innovation and collaboration. Therefore, we 
build the system portable solar cell for lighting. The concept of technology is simple and lowprices. The solar system was planted on the corner of the land. It could be the lighting for football matches, spiritual activities or a market.

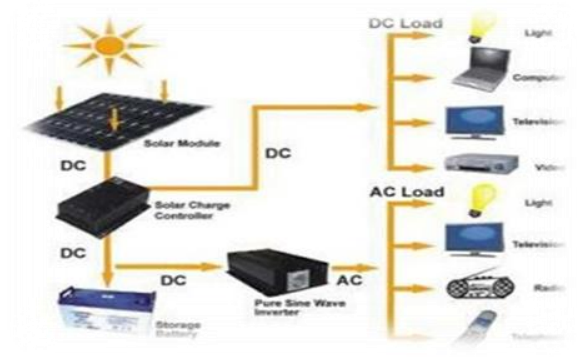
3 Power of Capasity $20 \mathrm{WP}-200 \mathrm{~W}$
3 solar cell $20 \mathrm{WP}+\mathrm{KABEL} 7 \mathrm{M}+$ Jach
3 Units Electric Box System ( EBS) $200 \mathrm{~W}$
3 Set Cable 35 Meters
12 Set Led Lamp $12 \mathrm{~V}-3 \mathrm{~W}=6 \mathrm{BH}$
3 balls of lamp $220 \mathrm{~V}-3 \mathrm{~W}$
Chain cable \& Fuse

Figure 1: Solar Cell and Its Specification

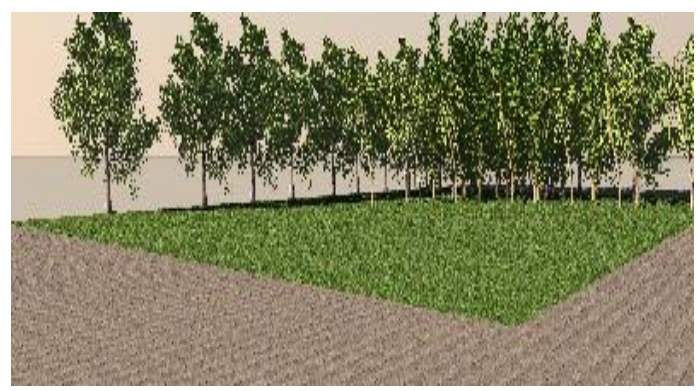

(a)

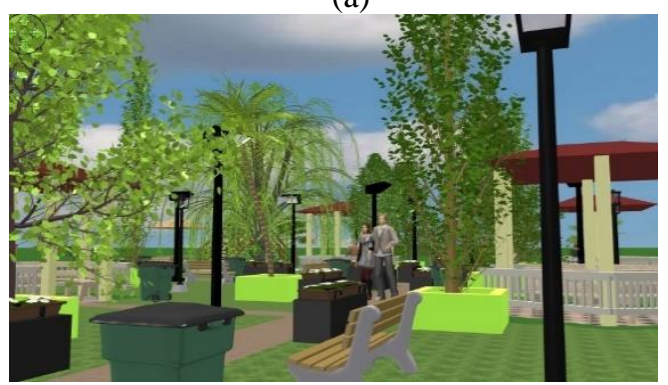

(c)

\begin{tabular}{|l|l|l|}
\hline Field & People & Development \\
\hline Unmanageable & $\begin{array}{l}\text { No } \\
\text { participation }\end{array}$ & Stagnant \\
\hline Unclean & Careless & No activity \\
\hline Spooky & Irrational & $\begin{array}{l}\text { No } \\
\text { investment }\end{array}$ \\
\hline Useless & Insensible & Worthless \\
\hline
\end{tabular}

(b)

\begin{tabular}{|l|l|l|}
\hline Field & People & Development \\
\hline Manageable & Participative & Forceful \\
\hline Clean & Manageable & $\begin{array}{l}\text { many } \\
\text { activities }\end{array}$ \\
\hline Comfortable & Rational & Investment \\
\hline Useful & Sensible & Worthful \\
\hline
\end{tabular}

(d)

Figure 2: (a) The description of field, people and Development (pre-applied integrated technology), (b) The description of field, people and Development (pre-applied integrated technology), (c) Illustration of Ideal Condition (post-applied integrated technology), (d) The description of field, people and development (post-applied integrated technology)

There are two condition; figure 2, the field before and after being built a portable solar cell. The first one, we can see that the field was untidy and worthless. It was forbidden to have any activitiy there. Others said it was too spooky being there so that around that are was unmanageable and dirty. The second one after being built a solar cell, people has been starting to clean it up. Starting to make an event like religous study, independence day or else. 

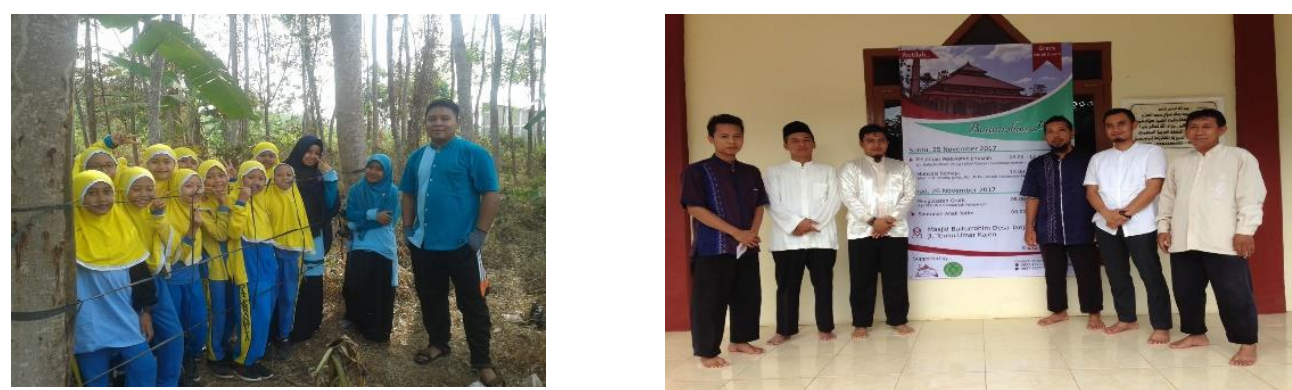

Figure 3: (a) The situation in the morning, (b) The situation on afternoon

Three communities; the football club, the student in Islamic Center and the group of business have been developing the land cooperatively. There is no more spooky after all. They created the mutual participation and togetherness even though people tend to have a priority scale. Choosing what is needed or not. No more spontaneous activity which was happened in five or ten years ago.

These graphic based on the activity around the field whichny one can participate in some activities: Football match, Jogging, sport school activity, Islamic studies, Ied Praying together and Market day. There is social participation in daily or weekly: cleaning together, family gathering and development by sub-district government; building lamp, road, sanitation, school and green house.

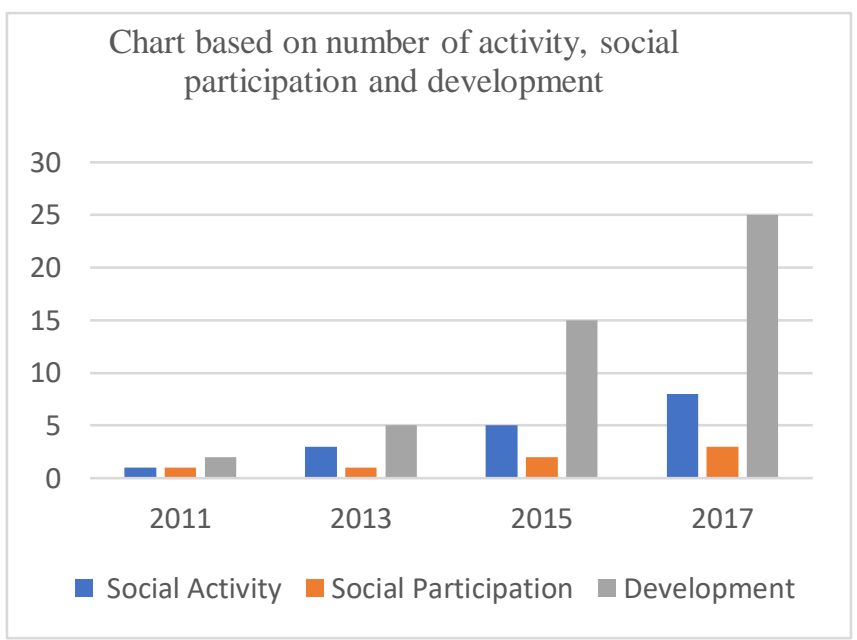

Figure 4

This chart is based on quantity of activity activity, participation and development. Every year it always raises up following the need, social awareness and integrated technology. For example by setting the solar cell for lighting, the need of science will raise up and it means the social awareness increases too. Therefore, it stimulates the development. In addition, It stimulates social participation in business community. It happened on RT 03, They built a mini hotel for the football club. They developed a market in front of it. RT05 made an open parking lot. Others made an organizer for the independent day, wedding or year ceremony. The role of one community can be the agent for the unity for the other community. 


\section{Conclusion}

In theory of education, that technology integration may create feelings of apprehension in some teachers because it is viewed as a second order change initiative [21]. We can analogize that the class is society/ people in village and teacher is someone or one community includes there. Teacher will stimulate the students to change their life better.[22] Teacher asked to learn something new, study new tool and force to apply useful things. Using technology is just helping them to reach the achievement and certain technologies change the options that are available, attractive, or salient to individuals [23]. And work together is the method how they find the problem and solve them collectively. The collectively. Social participation will create togetherness because mutual participation is form of social solidarity [24]. It is existing because of any external support which makes community inside intergrated. [25]. So by the mutual participation and innovation, the social changing has been starting to develop continuously.

\section{References}

[1] M. Abdul Rashid, "Modernity, tradition and modernity in tradition in Muslim societies," Intellect. DISCOURSE, no. 19, pp. 1-13, 2011.

[2] B. A. Saebani, "Pengantar Antropologi," Pustaka Setia, p. 2012.

[3] S.-R. S. Abbasi, M. B. Akram, and M. Shoaib, "Effect of Modern Lifestyle on Religious Practices," p. 8, 2013.

[4] K. Ahuja, M. van der Schaar, and W. R. Zame, "A Theory of Individualism, Collectivism and Economic Outcomes," ArXiv151201230 Phys. Q-Fin, Dec. 2015.

[5] S. Bret J. Sorensen et all, "ImplIcatIons for EducatIonal lEadErs as thEy consIdEr tEchnology dEvElopmEnt," Planing A, vol. 44, no. 1/2, pp. 73-86, 2013.

[6] B. Van Oers and M. Hännikäinen, "Some Thoughts About Togetherness: An introduction Re'flexions sur e Togetherness f Algunos Pensamientos Sobre el 'Sentimiento de Unio'n,"” Int. J. Early Years Educ., vol. 9, no. 2, pp. 101-108, Jun. 2001.

[7] J. W. Creswell, "Educational research Planning, conducting, and evaluating quantitative and qualitative research (4th ed.)," Pearson, p. 2012.

[8] Sugiyono, "Memahami Penelitian Kualitatif," Alfabeta, p. 2009

[9] V. W. Paul et all, Selecting the Right Analyses for your Data. New York and London: THE GUILFORD PRESS, 2014

[10] S. N. J., Toward a Theory of Modernization, Tribal and Peasant Economies: Readings in Economic Anthropology. Garden City, NY: Natural History Press, 1967.

[11] G. E. Reyes, "Four Main Theories Of Development: Modernization, Dependency, Word-System, And Globalization," Nómadas Rev. Crítica Cienc. Soc. Juríd., p. 16, 2001.

[12] J. May, "Egoism, Empathy, and Self-Other Merging," p. 14.

[13] H. B. Schmid, "PHILOSOPHICAL EGOISM: ITS NATURE AND LIMITATIONS," Econ. Philos., vol. 26, no. 02, pp. 217-240, Jul. 2010

[14] M. Parker \&. Henfield, M. S., "Exploring school counselors' perceptions of vicarious trauma: A qualitative study. The Professional Counselor," Prof. Couns., vol. 2, no. Reserach and Practice, pp. 134-142., 2012.

[15] J. Ranjabar, "Sistem sosial budaya Indonesia," Ghalia Indones., 2006.

[16] E. M. Rogers, "Diffusion of innovations," Free Press, 2003.

[17] W. Irwin, "Psychological Egoism and Self-Interest," vol. 39, no. 2, p. 22.

[18] S. V. Flynn and L. L. Black, "Altruism-Self-Interest Archetypes: A Paradigmatic Narrative of Counseling Professionals," Prof. Couns., vol. 3, no. 2, pp. 54-66, Oct. 2013.

[19] "358 Bottles Alchohol and 11 Mixed Bottles Is Found Before and After Chinese Religous Day." .

[20] E. D. Wiebe, "Integration of electronic mail into schools," J. Educ. Comput. Res., vol. 21, no. 1, pp. 55-73.

[21] M. R. J., Waters, T., McNulty, B. A., "School leadership that works: From research to results," Assoc. Su-Pervision Curric. Dev., 2015. 
[22] H. Darmadi, “Tugas, Peran, Kompetensi, Dan Tanggung Jawab Menjadi Guru Profesional,” vol. 13, no. 2, p. 14, 2015.

[23] I. Meijers, A, “Artefacts without agency," The Monist, vol. 3, no. 92, 2009.

[24] Subagyo, "Pengembangan Nilai Dan Tradisi Gotong Royong Dalam Bingkai Konservasi Nilai Budaya," Indones. J. Conserv., vol. 1, no. 1.

[25] R. Meta et all, "Nilai Gotong Royong Untuk Memperkuat Solidaritas Dalam Kehidupan Masyarakat Kampung Naga," vol. 6, no. 1, 2014. 